\title{
ピロリン酸浴からのCu-Zn合金めっき過程の 交流インピーダンス挙動
}

藤 原 裕*, 榎 本 英 彦 ${ }^{*}$

A. C. Impedance Behaviors during Electrodeposition of Cu-Zn Alloys from Pyrophosphate Baths

Yutaka FUJIWARA* and Hidehiko ENOMOTO*

Key Words : Brass Plating, Pyrophosphate Bath, A. C. Impedance

\section{1. 緒言}

$\mathrm{Cu}-\mathrm{Zn}$ 合金（黄銅）めっきは装飾めっきとして広く用 いられているが, 工業的に用いられている黄銅めっき浴 は毒性の強いシアン浴である。ピロリン酸浴は, ノーシ アンCu-Zn合金めっき浴として実用化の可能性のある浴 である ${ }^{1)}{ }^{2)}$ 。我々は, ピロリン酸浴にヒスチジンを添加 することにより広い電流密度範用で平滑な $\mathrm{Cu}-\mathrm{Zn}$ 合金めっ き皮膜が得られることを報告した ${ }^{3)}$ 。また，このことは, ヒスチジンと $\mathrm{Zn}^{2+}$ イオンを含むピロリン酸浴において, $\mathrm{Cu}$ 電析の部分電流が著しく小さいことと対応した ${ }^{4)} 。$ ヒスチジンの作用機構を明らかにするためには, 電気化 学的な測定が有効であると考えられる。そこで, 本研究 では, ピロリン酸浴からのCu-Zn合金電析時の交流イン ピーダンスを測定し，ヒスチジンの作用機構を考察した。

\section{2. 実験方法}

めっき浴組成は, $\mathrm{CuSO}_{4} \quad 0.1 \mathrm{M}, \mathrm{ZnSO}_{4} \quad 0 \sim 0.05 \mathrm{M}$,

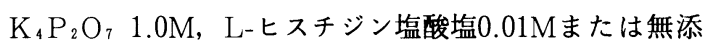
加であり, $\mathrm{pH}$ 調整は行わなかった。ヒスチジン添加浴 はpH9.3〜9.4, 無添加の浴はpH9.9〜10.0であった。陰 極（試料極）にはCu板, 対極にはPt被覆 $\mathrm{Ti}$ 板, 参照電 極には飽和 $\mathrm{KCl}$ 中の $\mathrm{Ag} / \mathrm{AgCl}$ 電極を用いた。浴温度 $30^{\circ} \mathrm{C}$, 無かくはんの条件でポテンショスタットを用いて 定電位電解を行った。以下に示す電極電位はすべて $\mathrm{Ag}$ / $\mathrm{AgCl}$ 電極基準の值である。電流電位曲線は定電位ス テップ法で測定した。

交流インピーダンス测定の際には, 定電位に保持した 試料極に, ポテンショスタットを介して $10 \mathrm{mV}_{\mathrm{P}-\mathrm{P}}$ の正 弦波を印加した。印加正弦波の周波数範囲は $50 \mathrm{mHz}$ $5 \mathrm{kHz}$ とした。ポテンショスタットの電位出力および電 流出力を 2 チャンネルFFTアナライザに入力し, チャ ンネル間の伝達関数を求めてインピーダンスを導出した。

* 大阪市立工業研究所（夏536 大阪市城東区森之宮1-6-50） Osaka Municipal Technical Research Institute (6-50, 1chome, Morinomiya, Joto-ku, Osaka 536)

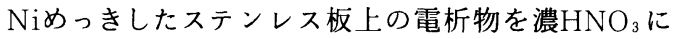
溶解し, 原子吸光法で分析することにより $\mathrm{Zn}$ の共析の 有無を確認した。

\section{3. 結果および考察}

ヒスチジン無添加の合金浴の電流電位曲線は分離の不 鮮明な二段波の形状を示し, Cu析出電流に対応する第 1 波は-1.1〜-1.2Vで, Zn析出電流に対応する第 2 波 はー1.4〜ー1.5Vで電流プラトーに達することを先に報

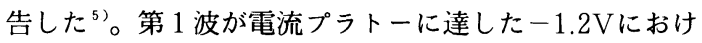
るCu単独浴および合金浴のインピーダンスの複素平面 プロットを図 1 に示す。いずれも低周波数側で傾き $45^{\circ}$ の直線状のWarburgインピーダンスの挙動を示し ている。すなわち, 第 1 波の電流プラトーは, $\mathrm{Cu}^{2+}$ オンの拡散限界電流を示している。したがって, ヒスチ ジン無添加のピロリン酸浴では, $\mathrm{Zn}$ はCu電析反応が拡 散律速に達した条件でのみ共析することが確認できた。

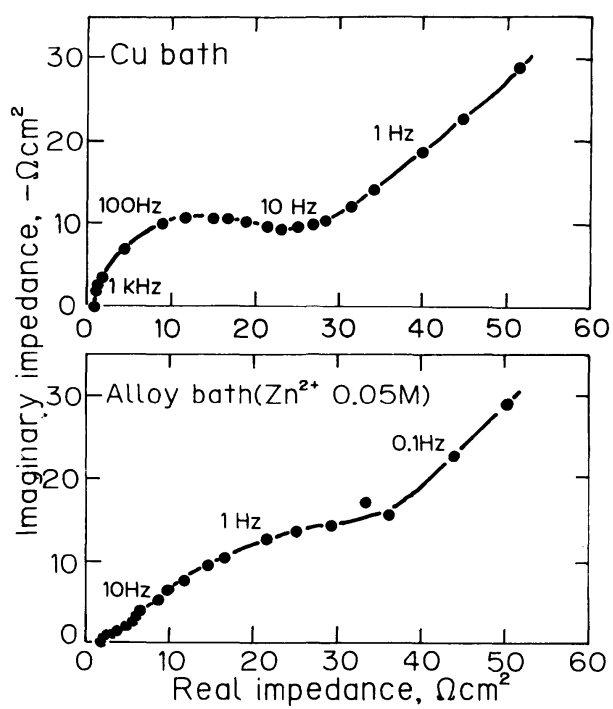

Fig. 1 Complex plane impedance plots obtained during $\mathrm{Cu}$ and $\mathrm{Cu}-\mathrm{Zn}$ alloy deposition from the pyrophosphate baths without histidine at $-1.2 \mathrm{~V}$ vs. $\mathrm{Ag} / \mathrm{AgCl}$. 


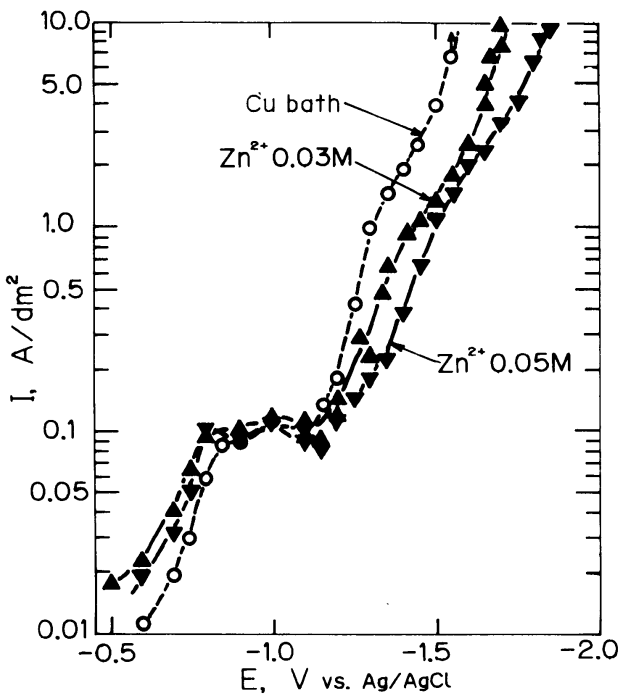

Fig. 2 Current density-potential curves of the pyrophosphate baths containing histidine.

ヒスチジン添加Cu単独浴および合金浴の電流電位曲 線を図 2 に示す。電流電位曲線には， $-0.8 \mathrm{~V} て ゙$ 明瞭な 電流プラトーが認められた。ヒスチジン無添加の浴の場 合には， $-0.8 \mathrm{~V} て ゙ は$ 第 1 波の電流プラトー $\left(\mathrm{Cu}^{2+}\right.$ イオ ンの拡散限界電流）に達しなかったら”。の電流プラトー までの電位領域では，ヒスチジン無添加浴の第 1 波の領 域之同様に，Cuだけが電析した。また，合金浴におけ る第 2 波の電流プラトーは明瞭に認められなくなった。 プラトーからの電流の立ち上がりの電位領域 $(-1.2 \mathrm{~V}$ より㒶な電位) では，水素発生が起こり，合金浴では Znが共析した。この電位領域では, $\mathrm{Zn}^{2+}$ イオン濃度が 大きい浴ほど電流が小さかった。すなわち， $\mathrm{Zn}^{2+}$ イオ ン濃度が大きい浴ほど合金電析の析出電位が卑である, という特徴的な挙動を示した。

ヒスチジン添加合金浴のインピーダンスプロットを図 3 に示す。電流がプラトーに達している $-1.2 \mathrm{~V}$ ，およ び, 電流が再び立ち上がり, Znが共析して平滑な合金 めっき皮膜が得られる-1.5Vにおけるインピーダンス を測定した。ー1.2Vにおけるプロットは歪んだ容量性 半円のみを示しており, Warburgインピーダンスの挙 動は認められなかった。したがって，ヒスチジン添加浴 における電流プラトーは, $\mathrm{Cu}^{2+}$ イオンの拡散限界電流 を示すむのではないと考えられる。電流電位曲線におけ る電流プラトーは, 電極反応が拡散律速である場合のほ か, 先行化学反応に律速されている場合にもみられると 考えられる ${ }^{6)}$ 。ヒスチジン添加浴からのCu電析反応に おける先行化学反応としては，たとえば，反応中間体の $\mathrm{Cu}^{+}$イオンと電極上に吸着したヒスチジンとの錯形成の ような反応が推察される。

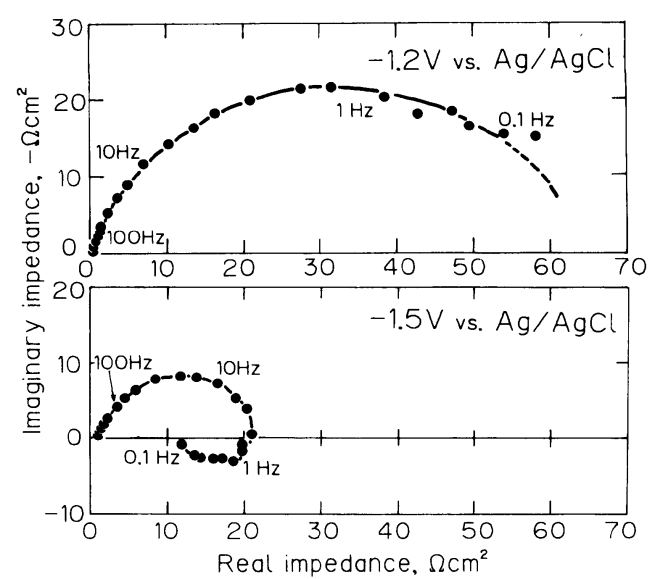

Fig. 3 Complex plane impedance plots obtained during $\mathrm{Cu}-\mathrm{Zn}$ alloy deposition from the pyrophosphate bath $\left(\mathrm{Zn}^{2+}\right.$ $0.05 \mathrm{M}$ ) containing histidine.

-1.5Vにおけるインピーダンスプロットには，高周 波数側の容量性半円に加えて低周波数側に誘導性の半円

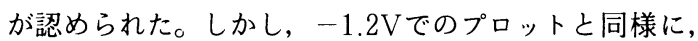
Warburgインピーダンスの挙動はまったく認められな かった。したがって， $\mathrm{Cu}^{2+}$ イオンの拡散律速下でZnが 共析するという合金電析機構は，ヒスチジン添加浴には あてはまらないと考えられる。インピーダンスプロット における誘導性の半円は，反応中間体の吸着の緩和 (coverage relaxation) を示しているという考え方 ${ }^{7}$ が最む一般的である。誘導性半円が認められたことは, ヒスチジン添加ピロリン酸浴からのCu-Zn合金電析過程 に吸着中間体が関与していることを示している。

\section{4. 結言}

ヒスチジン無添加のピロリン酸浴からは, $\mathrm{Cu}$ 電析反 応が拡散律速になる条件でのみZnが共析した。ヒスチ ジン添加浴からは, $\mathrm{Zn} は, \mathrm{Cu}$ の電析が拡散律速に達し ていない条件においても共析した。また，合金電析過程 への吸着中間体の寄与が示唆された。

(1989-10-14 受理)

\section{文献}

1 ) T. Vagramyan, J. S. L. Leach, J. R. Moon ; Electrochim. Acta, 24, 231 (1979)

2 ) 藤原 裕, 榎本英彦; 科学と工業, 61，460 (1987)

3 ）藤原 裕, 榎本英彦; 表面技術，40，136（1989）

4 ）藤原 裕, 榎本英彦; 表面技術, 投稿中

5 ）藤原 裕，榎本英彦; 金属表面技術，37，411（1986）

6 ) 玉虫伶太; 電気化学, p.248（東京化学同人, 1967)

7 ) I. Epelboin and R. Wiart : J. Electrochem. Soc., 118, 1577 (1971) 